\title{
Repetition Number
}

National Cancer Institute

\section{Source}

National Cancer Institute. Repetition Number. NCI Thesaurus. Code C93651.

An integer that identifies the particular occurrence of a repeating activity or entity. 